\title{
Državni zbor v času priprav in izvedbe predsedovanja Republike Slovenije Svetu Evropske unije
}

\author{
UDK: 328(497.4):061.1EU \\ Lovro Lončar \\ lovro.loncar@gmail.com
}

\section{IZVLEČEK}

Slovenija je v času od 1. januarja 2008 do 30 . junija 2008 kot prva nova članica Evropske unije (EU) predsedovala Svetu EU. Državni zbor Republike Slovenije je že v začetku leta 2005 pristopil k začetku priprav in aktivnosti v času predsedovanja Svetu EU v okviru tradicionalne vloge, ki jo imajo parlamenti držav članic EU, ki predsedujejo Svetu EU.

Državni zbor Republike Slovenije je imel pri pripravah in izvedbi aktivnosti $v$ času predsedovanja posebno, specifično vlogo. Aktivnosti so zahtevale poseben pristop $v$ vodenju in koordiniranju t.i. "projekta predsedovanja" $v$ okviru Državnega zbora Republike Slovenije. V članku so prikazane ključne aktivnosti pred in med predsedovanjem Svetu EU v Državnem zboru RS, predvsem priprave na dogodke in njihovo samo izvedbo, ki so uporabne v vsakem času za izvedbo podobnih nalog oz. projektov.

Ključne besede: Državni zbor Republike Slovenije, predsedovanje Svetu EU, organizacijske priprave, projektna skupina, službe Državnega zbora

JEL: 022 
Lovro Lončar

Državni zbor v času priprav in izvedbe predsedovanja

Republike Slovenije Svetu Evropske unije

\section{Uvod}

$\checkmark$ času predsedovanja nacionalni parlamenti predsedujejo medparlamentarnim zasedanjem na treh ravneh (Državni zbor, 2006):

1. Predsedovanje Konferenci odborov za evropske zadeve (COSAC), ki jo sestavljajo do šestčlanske delegacije parlamentarnih odborov za evropske zadeve držav članic EU in Evropskega parlamenta, kot opazovalci pa so vabljeni tudi po trije predstavniki držav kandidatk.

2. Medparlamentarna srečanja drugih odborov nacionalnih parlamentov, ki jih organizira predsedstvo. Poleg srečanja odborov za zunanjo politiko, ki je stalnica vsakega predsedovanja, lahko nacionalni parlament predsedujoče države organizira tudi srečanja nekaterih drugih odborov. Po tradiciji so to tri do štiri srečanja, na katera so vabljeni predsedniki delovnih teles obeh domov parlamentov (v primeru dvodomnosti) držav članic EU, pristopnic in kandidatk ter predstavniki Evropskega parlamenta.

3. Medparlamentarna srečanja $v$ sodelovanju z Evropskim parlamentom (EP) - sopredsedovanje skupnim medparlamentarnim srečanjem $\mathrm{v}$ Bruslju. Gre za dva tipa srečanj: skupna srečanja odbora EP z delegacijami nacionalnih parlamentarnih odborov in horizontalna srečanja.

Vse navedene aktivnosti so potekale tudi v času predsedovanja Slovenije Svetu EU (v nadaljevanju: predsedovanje): konferenca COSAC maja 2008 na Brdu; $\vee$ veliki dvorani Državnega zbora šest medparlamentarnih srečanj odborov nacionalnih parlamentov; tri medparlamentarna srečanja $v$ soorganizaciji z Evropskim parlamentom v Bruslju; Državni zbor Republike Slovenije ( v nadaljevanju: Državni zbor) pa je gostil tudi obisk predsednika Evropskega parlamenta; sestanek predsednikov parlamentov t.i. predsedujočega tria (Nemčije, Portugalske, Slovenije) in Francije kot naslednje predsedujoče države ter predsednika Evropskega parlamenta; sodeloval je pri izvedbi Kolokvija Skupščine Zahodnoevropske unije (ZEU) in pri realizaciji srečanja Transatlantskega zakonodajnega dialoga. 


\section{Odločitev za predsedovanje}

Novembra leta 2004 je bila Sloveniji ponujena priložnost, da kot prva nova članica EU po širitvi EU leta 2004 prevzame v skladu s predlaganim načrtom predsedovanja posameznih članic EU predsedovanje Svetu EU. Na tej podlagi je Vlada Republike Slovenije ( $v$ nadaljevanju: Vlada) 10. novembra 2004 v Državni zbor Republike Slovenije predložila Informacijo o vrstnem redu predsedovanja Svetu Evropske unije in Evropskemu svetu po letu 2006 (Vlada, 2004). $\checkmark$ skladu z Zakonom o sodelovanju med državnim zborom in vlado $v$ zadevah Evropske unije (Uradni list RS, štev. 34/2004) je Kolegij predsednika Državnega zbora na svoji seji dne 16. 11. 2004 sprejel sklep, da Državni zbor na seji obravnava in sprejme stališče Republike Slovenije o predsedovanju Slovenije Svetu Evropske unije in Evropskemu svetu.

Glede na to, da je bil takrat že začet postopek sprejema Pogodbe o ustavi za Evropo po članicah EU, je Državni zbor na predlog Vlade naslednji dan po kolegiju na seji sprejel stališče Republike Slovenije, da »v primeru, da Pogodba o Ustavi za Evropo stopi v veljavo do konca leta 2006, Republika Slovenija sprejme predsedovanje Svetu Evropske unije $\vee$ prvi skupini držav, v obdobju od 1. 1. 2007 do 30. 6. 2008, in ga, $\vee$ primeru, da se predsedovanje ne bo izvajalo skupno, izvaja v prvi polovici leta 2008. V primeru, da Pogodba o ustavi za Evropo ne stopi $\vee$ veljavo do konca leta 2006, Republika Slovenija sprejme predsedovanje Evropskemu Svetu in Svetu Evropske unije v prvi polovici leta 2008 « (Vlada, 2004). S to odločitvijo in kasneje $v$ Bruslju s potrditvijo našega predsedovanja so se dejansko začele vsebinske in tehnične priprave na predsedovanje. Glede na znana dejstva o kasnejšem postopku sprejema Pogodbe o ustavi za Evropo po članicah EU je Slovenija torej predsedovala v prvi polovici leta 2008.

\section{Vsebinske priprave na predsedovanje $v$ Državnem zboru}

Vlada je bila v skladu s svojo ustavno vlogo in pristojnostmi nosilka aktivnosti predsedovanja, kar pomeni, da je imela nosilno vlogo in odgovornost pri predsedovanju, seveda pa sta ob vsakem predsedovanju posamezne članice 
Lovro Lončar

Državni zbor v času priprav in izvedbe predsedovanja

Republike Slovenije Svetu Evropske unije

pomembni tudi vloga in aktivnost nacionalnih parlamentov ter drugih institucij in organov. Predsedovanje je nacionalni projekt.

Vsebinska določitev aktivnosti za čas predsedovanja je po sami odločitvi o sprejemu predsedovanja najpomembnejša odločitev Državnega zbora. K določitvi aktivnosti $\vee$ času predsedovanja je Državni zbor pristopil $\vee$ začetku leta 2006 .

Ključne odločitve v zvezi z aktivnostmi Državnega zbora v obdobju priprav in predsedovanja je sprejemal kolegij predsednika Državnega zbora. Aktivnosti je vodil oziroma usklajeval predsednik Državnega zbora $v$ sodelovanju z generalnim sekretarjem Državnega zbora in projektno skupino v Državnem zboru za pripravo na predsedovanje Republike Slovenije Evropski uniji od 1. 1. 2008 do 30. 6. 2008 (v nadaljevanju: projektna skupina) (Državni zbor, 2006b). Pri tem je bilo izredno pomembno, da je bil predhodno usklajen časovni plan rednega dela Državnega zbora, program predsedovanja na parlamentarni ravni in program drugih mednarodnih aktivnosti v času predsedovanja v Državnem zboru. Generalni sekretar Državnega zbora je $\vee$ sodelovanju s projektno skupino redno seznanjal kolegij predsednika Državnega zbora o poteku priprav na predsedovanje v Državnem zboru.

Na posvetu z vodji poslanskih skupin je bilo v začetku marca 2006 na predlog strokovnih služb Državnega zbora obravnavano gradivo Predlog priprav na predsedovanje Republike Slovenije Svetu EU od 1. 1. 2008 do 30. 6. 2008 parlamentarni vidik (Državni zbor, 2006), iz katerega so bile razvidne možne okvirne vsebinske aktivnosti oz. obveznosti v Državnem zboru v času predsedovanja. Gradivo so obravnavali tudi predsedniki delovnih teles.

Parlamentarni vidik oz. obseg predsedovanja EU posameznih nacionalnih parlamentov doslej ni bil nikoli formalno določen oz. opredeljen, saj je odločitev o vključenosti posameznega nacionalnega parlamenta $\vee$ proces predsedovanja posamezne članice EU bolj stvar tradicije kot dejanskih formalnih obveznosti nacionalnih parlamentov. Edini dokument, ki opredeljuje sodelovanje nacionalnih parlamentov $v$ času predsedovanja, so t.i. Haške smernice (Smernice o medparlamentarnem sodelovanju, sprejete na Konferenci predsednikov parlamentov držav članic EU v Haagu dne 3. 7. 2007). O metodah, načinih in vzorcih sodelovanja nacionalnih parlamentov $\vee$ času predsedovanja občasno razpravljajo tudi predsedniki parlamentov držav članic EU, kandidatk in Evropskega parlamenta. Stopnja vključenosti $\vee$ proces predsedovanja je torej avtonomna odločitev posameznega nacionalnega parlamenta. Formalno so $v$ skladu s protokolom k Amsterdamski pogodbi (Protokol o vlogi nacionalnih parlamentov $v$ 
EU, 1997) obvezna le srečanja COSAC, tradicionalno pa je zaželjeno srečanje odborov za zunanjo politiko (COFACC). Iz dosedanjih predsedovanj se pri organizaciji srečanj $\vee$ času predsedovanja nacionalnih parlamentov največkrat uporablja model, pri katerem organizirajo več srečanj odborov (poleg omenjenih dveh vsaj še tri ali štiri srečanja odborov) ter pri določitvi odborov sledijo pretekli praksi držav, ki so že predsedovale, in predvsem konkretnemu programu predsedovanja.

Državni zbor je poglavitne informacije o metodologiji in o načinih predsedovanja črpal iz izkušenj avstrijskega predsedstva, čeprav je bil pred tem narejen krajši vsebinski pregled predsedovanj in praks ter standardov držav, ki so predsedovale Svetu EU pred Slovenijo.

Avstrijski model predsedovanja na parlamentarni ravni je službam Državnega zbora pri pripravah in izvedbi predsedovanja služil kot najprimernejši vzorec iz več razlogov (Državni zbor se na politični ravni ni nikoli odločal o tem, kateremu dosedanjemu modelu bo sledil pri izvedbi predsedovanja). Poleg geografske in časovne bližine predsedovanja (Avstrija je predsedovala EU $\vee$ času, ko je Slovenija začela s pripravami), je Avstrija na parlamentarnem nivoju predsedovala s številčno relativno zelo majhnimi kadrovskimi resursi, kar je bil tudi cilj služb Državnega zbora. Avstrija je k predsedovanju pristopila sistematično in je imela pozitivne izkušnje na področju organiziranja skupnih parlamentarnih srečanj v Bruslju, ki jih organizirata evropski parlament in nacionalni parlament, ter skupnih srečanj odborov, njen proračun za predsedovanje je bil primerljiv $s$ finančnimi načrti stroškov za predsedovanje $v$ Državnem zboru. Finski model parlamentarnega predsedovanja, s katerim so se službe tudi seznanile, je bil organizacijsko glede na strukturo in pristojnosti znotraj parlamenta preveč poseben, portugalski model pa je bil za obseg slovenskega predsedovanja stroškovno in kadrovsko preobširen.

Odločitve, katera srečanja bo $v$ času predsedovanja organiziral Državni zbor, so torej temeljile na prioritetah predsedovanja Slovenije EU in na dosedanjih praksah pri parlamentarnem predsedovanju ter na vsebinskih prioritetah posameznih delovnih teles (odborov) $\vee$ Državnem zboru.

Prvo formalno odločitev $v$ zvezi $z$ načinom priprav na predsedovanje $v$ Državnem zboru je kolegij predsednika Državnega zbora obravnaval dne 14. julija 2006, ko so člani kolegija sprejeli predlog aktivnosti Državnega zbora v obdobju predsedovanja EU od 1. 1. 2008 do 30. 6. 2008 (Državni zbor, 2006a), s katerim so določili usklajene datume srečanj delovnih teles, ki bodo organizirala srečanja predsednikov odborov $\vee$ času predsedovanja, $s$ celotnim koledarjem 
Lovro Lončar

Državni zbor v času priprav in izvedbe predsedovanja

Republike Slovenije Svetu Evropske unije

predsedovanja Slovenije, saj je pomembno, da se datumi ključnih srečanj med predsedovanjem ne prekrivajo tako z vsebinskega vidika kot z vidika udeležbe gostov.

Najtežje je bilo uskladiti in določiti delovna telesa, ki bodo imela srečanja $v$ Državnem zboru. Po odločitvi kolegija naj bi poleg sestanka predsedniške trojke COSAC in XXXIX. zasedanja COSAC, ki sta določena v poslovniku COSAC, ter tradicionalne konference predsednikov Odborov za zunanjo politiko, določili še srečanja štirih odborov. Na delovnih pogovorih se je namreč izkazalo, da je za organizacijo srečanj in za nekatere teme zainteresiranih več odborov in da bi ob tem posamezno srečanje lahko soorganizirala tudi po dva odbora (Državni zbor, 2007).

Na 95. seji Kolegija predsednika Državnega zbora dne 20. aprila 2007 je bil potrjen časovni in vsebinski razpored sestankov odborov nacionalnih parlamentov (Državni zbor, 2007a), ki so potekali $\vee$ Državnem zboru $\vee$ času predsedovanja, hkrati pa se je Kolegij seznanil z informacijo o predvidenih medparlamentarnih srečanjih $v$ sodelovanju z Evropskim parlamentom ter drugih možnih srečanjih $\vee$ Državnem zboru $\vee$ času predsedovanja (npr.: srečanje Skupščine Zahodnoevropske unije in srečanje Transatlantskega zakonodajnega dialoga). Kolegij predsednika Državnega zbora je program dokončno dopolnil julija 2007 s srečanjem odborov za obrambo in srečanjem Skupščine Zahodnoevropske unije.

Državni zbor se je na svoji 34. redni seji dne 18. decembra 2007 seznanil z Informacijo o dejavnostih Državnega zbora Republike Slovenije v času predsedovanja Republike Slovenije Svetu Evropske unije (januar-junij 2008) - EPA 1784-IV (Državni zbor, 2007b). Slovenija je do sedaj po dostopnih informacijah tudi edina predsedujoča država, ki je o temah (vsebini) posameznih parlamentarnih srečanj pred nastopom predsedovanja razpravljala $\vee$ obliki informacije na plenarni seji parlamenta (na seji Državnega zbora). $S$ tem je bila tudi širša javnost seznanjena z vsebinskimi parlamentarnimi poudarki predsedovanja EU.

Dogodki oz. srečanja so bili zaprti za javnost, z izjemo srečanja trojke COSAC in XXXIX. zasedanja COSAC, ki sta po poslovniku javna, ter Konference predsednikov odborov za obrambo in Odborov za kulturo.

Predsednika Državnega zbora in Državnega sveta sta 23. oktobra 2007 podpisala Dogovor o sodelovanju Državnega zbora in Državnega sveta pri usmerjanju aktivnosti v času priprav na predsedovanje in v času predsedovanja Republike Slovenije Svetu Evropske unije (Državni zbor, 2007c). V dogovoru sta opredelila način sodelovanja pri srečanju odborov, srečanjih z Evropskim parlamentom ter 
način delitve stroškov pri organizaciji skupnih dogodkov. Po zbranih informacijah je to prvi tovrstni formalni dogovor o pripravah in izvedbi predsedovanja med dvema domovoma, morda tudi iz razloga specifičnosti ustavnega položaja in pristojnosti ter Državnega zbora in Državnega sveta ( $v$ drugih državah je sistem dvodomnosti bolj jasen in definiran $\vee$ smislu pristojnosti posameznih domov $\vee$ mednarodnih zadevah - t.i. popolni dvodomni sistem). Sporazum je izhajal iz ustavne in zakonske opredelitve položaja in pristojnosti Državnega zbora in Državnega sveta, $v$ želji po usklajenem in uspešnem sodelovanju med obema domovoma $\vee$ času predsedovanja EU. Bistvo dogovora je bila tehnična razdelitev pristojnosti pri organizaciji srečanj nacionalnih parlamentov, kjer je poudarjena vodilna vloga Državnega zbora in sestava delegacij v razmerju $2: 1 \vee$ korist Državnega zbora.

Preglednica 1: Koledar dogodkov, povezanih s predsedovanjem Republike Slovenije Svetu Evropske unije

\begin{tabular}{|c|c|c|}
\hline DATUM & DOGODEK & DELOVNO TELO \\
\hline \multicolumn{3}{|l|}{2007} \\
\hline 11. in 12. oktober & $\begin{array}{l}\text { Obisk Odbora za zunanjo politiko } \\
\text { EP (AFET) v RS }\end{array}$ & Odbor za zunanjo politiko \\
\hline 17. in 18. oktober & $\begin{array}{l}\text { Obisk Odbora za razvoj EP } \\
\text { (DEVE) v RS }\end{array}$ & $\begin{array}{l}\text { Odbor za zunanjo politiko } \\
\text { Odbor za gospodarstvo } \\
\text { Predsednik DZ }\end{array}$ \\
\hline 18. oktober & $\begin{array}{l}\text { Obisk Odbora za zaposlovanje in } \\
\text { socialne zadeve EP (EMPL) v RS }\end{array}$ & $\begin{array}{l}\text { Odbor za delo, družino, socialne } \\
\text { zadeve in invalide } \\
\text { Odbor za zadeve EU }\end{array}$ \\
\hline 26. in 27. november & $\begin{array}{l}\text { Obisk Odbora za gospodarstvo in } \\
\text { monetarne zadeve EP (ECON) v } \\
\text { RS }\end{array}$ & $\begin{array}{l}\text { Odbor za gospodarstvo } \\
\text { Odbor za finance in monetarno } \\
\text { politiko }\end{array}$ \\
\hline 30. november & $\begin{array}{l}\text { Obisk odbora za pravne zadeve } \\
\text { EP (JURI) v RS }\end{array}$ & $\begin{array}{l}\text { Odbor za notranjo politiko, javno } \\
\text { upravo in pravosodje }\end{array}$ \\
\hline 20. december & $\begin{array}{l}\text { Obisk Konference predsednikov } \\
\text { Evropskega parlamenta } \vee \mathrm{RS}- \\
\text { dialog z mladimi }\end{array}$ & $\begin{array}{l}\text { Predsednik Državnega zbora in } \\
\text { Kolegij predsednika Državnega } \\
\text { zbora }\end{array}$ \\
\hline
\end{tabular}




\section{Lovro Lončar \\ Državni zbor v času priprav in izvedbe predsedovanja \\ Republike Slovenije Svetu Evropske unije}

\begin{tabular}{|c|c|c|}
\hline 8. januar & $\begin{array}{l}\text { Obisk predsednika Evropskega } \\
\text { parlamenta }\end{array}$ & Predsednik Državnega zbora \\
\hline 11. januar & $\begin{array}{l}\text { Sestanek predsednikov parla- } \\
\text { mentov predsedujočega Tria in } \\
\text { Francije ter predsednika Evrop- } \\
\text { skega parlamenta }\end{array}$ & $\begin{array}{l}\text { Predsednik Državnega zbora } \\
\text { Predsednik Odbora za zadeve } \\
\text { Evropske unije } \\
\text { Predsednik Odbora za zunanjo } \\
\text { politiko }\end{array}$ \\
\hline 21. januar & $\begin{array}{l}\text { Srečanje predsednikov odborov, } \\
\text { pristojnih za energetiko }\end{array}$ & $\begin{array}{l}\text { Predsednik Odbora za gospodars- } \\
\text { tvo } \\
\text { Predsednik Odbora za okolje in } \\
\text { prostor }\end{array}$ \\
\hline 11. in 12. februar & $\begin{array}{l}\text { Skupno parlamentarno srečanje o } \\
\text { Lizbonski strategiji (v sodelovanju } \\
\text { z Evropskim parlamentom) }\end{array}$ & $\begin{array}{l}\text { Predsednik Državnega zbora } \\
\text { Predsednik Odbora za gospodars- } \\
\text { tvo } \\
\text { Predsednik Odbora za delo, druži- } \\
\text { no, socialne zadeve in invalide } \\
\text { član Odbora za zadeve Evropske } \\
\text { unije }\end{array}$ \\
\hline 17. in 18. februar & $\begin{array}{l}\text { Srečanje predsednikov parlamen- } \\
\text { tarnih odborov za evropske zade- } \\
\text { ve in Trojke }\end{array}$ & $\begin{array}{l}\text { Predsednik Odbora za zadeve } \\
\text { Evropske unije }\end{array}$ \\
\hline 2. in 3. marec & $\begin{array}{l}\text { Konferenca predsednikov Odbo- } \\
\text { rov za obrambo }\end{array}$ & Predsednik Odbora za obrambo \\
\hline 4. in 5. marec & Kolokvij Skupščine ZEU & $\begin{array}{l}\text { Delegacija Državnega zbora } v \\
\text { Skupščini ZEU }\end{array}$ \\
\hline 17. in 18. marec & $\begin{array}{l}\text { Konferenca predsednikov Odbo- } \\
\text { rov za zunanjo politiko }\end{array}$ & $\begin{array}{l}\text { Predsednik Odbora za zunanjo } \\
\text { politiko }\end{array}$ \\
\hline 14. april & $\begin{array}{l}\text { Srečanje predsednikov Odborov } \\
\text { za kulturo, šolstvo in šport }\end{array}$ & $\begin{array}{l}\text { Predsednik Odbora za kulturo, } \\
\text { šolstvo in šport }\end{array}$ \\
\hline 7. in 8. maj & XXXIX. zasedanje COSAC & Odbor za zadeve Evropske unije \\
\hline 24. in 25. maj & Transatlantski zakonodajni dialog & Predsednik Državnega zbora \\
\hline 26. in 27. maj & $\begin{array}{l}\text { Skupno parlamentarno srečanje } \\
\text { „Doseganje Evropske perspekti- } \\
\text { ve za Jugovzhodno Evropo" (v } \\
\text { sodelovanju z Evropskim parla- } \\
\text { mentom) }\end{array}$ & $\begin{array}{l}\text { Predsednik Državnega zbora } \\
\text { Predsednik Odbora za zunanjo } \\
\text { politiko } \\
\text { Predsednik Odbora za zadeve } \\
\text { Evropske unije }\end{array}$ \\
\hline 2. junij & $\begin{array}{l}\text { Srečanje predsednikov Odborov } \\
\text { za kmetijstvo, gozdarstvo in } \\
\text { prehrano }\end{array}$ & $\begin{array}{l}\text { Predsednica odbora za kmetijstvo, } \\
\text { gozdarstvo in prehrano }\end{array}$ \\
\hline 26. junij & $\begin{array}{l}\text { Skupno srečanje parlamentarnih } \\
\text { odborov za razvoj (v sodelovanju } \\
\text { z Evropskim parlamentom) }\end{array}$ & član Odbora za zunanjo politiko \\
\hline
\end{tabular}

Vir: Informacija o dejavnostih Državnega zbora Republike Slovenije v času predsedovanja Republike Slovenije Svetu Evropske unije (januar-junij 2008) - EPA 1784-IV (Državni zbor, 2007b.) 
Za vsebinsko pripravo parlamentarnih srečanj so bila odgovorna posamezna delovna telesa (predsedniki odborov oz. strokovne službe Državnega zbora), kar pomeni odgovornost za določitev tem, govornikov, uskladitev programa, spremljanje poteka sestanka, pripravo morebitnih zaključkov itd.

Srečanja $\vee$ okviru predsedovanja na parlamentarnem nivoju $v$ temelju niso strukturirana tako, da bi nujno vodila do skupnih formalnih sklepov in enotnih zaključkov, gre bolj za razpravo parlamentarcev o ključnih, aktualnih izzivih predsedovanja, s poudarki na koledarju aktivnosti in prioritetah predsedujoče države, gre za seznanjanje predsedujočih o vsebinskih prioritetah formacijam Sveta EU, za izmenjavo mnenj s predstavniki Evropske komisije ter parlamenta.

Tako je bilo srečanje Odbora za energetiko in okolje parlamentov držav članic EU, Evropskega parlamenta in parlamentov držav kandidatk namenjeno razpravi o trajnostni energetski politiki EU $s$ poudarkom na sodelovanju $\mathrm{s}$ sosednjimi regijami ter na podnebnih spremembah $\vee$ luči novega podnebnoenergetskega paketa Evropske komisije. Razprava je bila posvečena tudi energetskemu sodelovanju $\vee$ Jugovzhodni Evropi, katere politična stabilnost je ključna za razvoj regije, hkrati pa je to tudi pogoj za gospodarsko in energetsko stabilnost.

V okviru srečanja predsedniške trojke COSAC ter XXXIX. zasedanja COSAC je bil poudarek na pregledu sodelovanja med Evropsko komisijo in nacionalnimi parlamenti ter specifičnih temah, predvsem je bil namenjen razpravi o sodelovanju med Evropsko komisijo in nacionalnimi parlamenti o približevanju Evropske unije njenim državljanom ter medgeneracijski solidarnosti z aktivnim vključevanjem starejših $v$ družbo. Udeleženci srečanja so razpravljali tudi o izzivih, povezanih s sodelovanjem Evropske unije z državami Zahodnega Balkana na področju notranjih zadev. Ob začetku novega triletnega obdobja izvajanja prenovljene Lizbonske strategije je bila na majskem srečanju $v$ središču pozornosti tudi razprava o doseganju ciljev te strategije, ki bo usmerjena na prenos inovacij $\vee$ gospodarstvo in na večanje konkurenčnosti $v$ povezavi z odgovornim ravnanjem z okoljem kot odzivom na podnebne spremembe.

Odbor za obrambo je na svojem srečanju razpravljal o glavnih aktivnostih evropske varnostne in obrambne politike $\mathrm{v}$ času slovenskega predsedovanja, $\mathrm{ki}$ so bile usmerjene zlasti na področja Zahodnega Balkana, na operacije kriznega odzivanja, na razvoj in krepitev vojaških zmogljivosti ter na razvoj evropske obrambne agencije.

Odbor za zunanjo politiko se je na svojem srečanju osredotočil na številne aktualne zunanjepolitične izzive: vprašanje skupne zunanje politike unije, širitev 
Lovro Lončar

Državni zbor v času priprav in izvedbe predsedovanja

Republike Slovenije Svetu Evropske unije

EU, evropsko sosedsko politiko, odnose s strateškimi partnerji. Na srečanju je bila posebna pozornost namenjena predvsem evropski perspektivi držav Zahodnega Balkana, kar je bila tudi ena izmed prioritet slovenskega predsedstva.

Odbor za kulturo je razpravljal o pomenu, različnih vidikih in ciljih medkulturnega dialoga, ki so bili v evropskem letu medkulturnega dialoga pomemben dejavnik evropskega združevanja in uresničevanja skupnih ciljev. Ključni cilj razprave je bil pri državljanih EU in politiki ozavestiti pomen kulture in še posebej medkulturnega dialoga, spoznati, kako pomembno je strateško poznavanje in zagotavljanje doslednega spoštovanja bogastva različnih kultur in jezikovne raznolikosti v Evropi, kar naj bi med evropskimi državljani okrepilo zavedanje o skupnih vrednotah kot trajnemu temelju Evropske unije. Odbor za kmetijstvo se je osredotočil na vprašanje prihodnosti Skupne kmetijske politike in prehranske varnosti ter vpliv podnebnih sprememb na kmetijsko proizvodnjo.

\section{Organizacijske priprave na predsedovanje v Državnem zboru}

\subsection{Ustanovitev projektne skupine}

Državni zbor je moral tudi zaradi pravočasnih organizacijskih priprav čim prej sprejeti odločitev, katera srečanja bo gostil in kdaj, da so lahko v strokovnih službah Državnega zbora pristopili k organizacijskim pripravam za njihovo izvedbo. Organizacijska posebnost slovenskega predsedovanja je bila številčno kadrovska skromnost, ki pa se je operativno izkazala za dobro odločitev. Po informacijah je bila slovenska posebnost tudi posebna skupina, ki se je ukvarjala z vsemi vprašanji predsedovanja. Po potrebi in v skladu z nalogami so bile v priprave in izvedbo projekta vključene vse službe Državnega zbora.

Generalni sekretar je za izvedbo aktivnosti $\vee$ času predsedovanja aprila 2006 s sklepom ustanovil in imenoval petčlansko projektno skupino za priprave na predsedovanje, ki se je po potrebi kadrovsko dopolnjevala (Državni zbor, 2006b). Naloga projektne skupine je bila priprava in izvedba vseh aktivnosti za dogodke Državnega zbora $v$ času predsedovanja in ob tem tudi koordinacija $z$ Vlado. Pomembno je izpostaviti zelo dobro sodelovanje in koordinacijo s službami Vlade, s čimer je bilo preprečeno morebitno podvajanje aktivnosti in predvsem zmanjšanje nepotrebnih dodatnih stroškov (npr. darila, prevozi, varovanje ...). 
Njihovo kakovostno delo je zagotovo odločilno prispevalo k uspešni organizacijski izvedbi programa.

Projektna skupina je bila gonilna sila organizacijskih priprav na predsedovanje. V času priprav so člani skupine obiskali avstrijski in portugalski parlament, kjer so predstavili svoje izkušnje $\vee$ zvezi s predsedovanjem. Takoj po imenovanju projektne skupine za pripravo na predsedovanje in oblikovanju delovnih podskupin za vsebinsko pripravo posameznih dogodkov je bil skupni sestanek z vsemi vodji služb in uslužbenci v Državnem zboru, vključenimi v projekt predsedovanja, in predsedniki delovnih teles (odborov). Na sestanku sta bila predstavljena koncept in organizacijska struktura priprav in izvedbe posameznih dogodkov, porazdeljene so bile naloge in obveznosti, da bi s tem preprečili morebitna podvajanja aktivnosti oz. pristojnosti.

\subsection{Organizacijske naloge}

Vsako srečanje je zahtevalo posebno pripravo in prilagoditev specifičnim zahtevam dogodka. Slovenija in Ljubljana, kot glavno mesto, sta logistično omejeni in zaradi tega je bila potrebna skrbna koordinacija datumov posameznih dogodkov zaradi morebitnih logističnih problemov, kot so npr. hotelske namestitve. $\checkmark$ glavnem so bile naloge za organizacijo srečanja naslednje:

- priprava in lokalna organizacija sestanka,

- zagotovitev ustreznega števila sob v hotelih,

- prevoz udeležencev $v$ okviru programa,

- zagotovitev pisnih prevodov gradiv $v$ slovenski, angleški in francoski jezik,

- namestitev in uporaba opreme za simultano prevajanje, avdio-video opreme v sejnih dvoranah, vključno s tehnično pomočjo,

- zagotovitev različnih storitev za udeležence sestanka - telefon, telefaks, dostop do internetne povezave ...,

- uradni obedi oz. sprejemi,

- pijača (kava, čaj, sokovi, voda) med odmori,

- ustno prevajanje $v$ angleščino, francoščino in slovenščino,

- razmnoževanje dokumentov za zasedanje,

- stroški bivanja povabljenih govornikov (po potrebi),

- kulturna promocija (razstave, umetniški nastopi ...). 
Lovro Lončar

Državni zbor v času priprav in izvedbe predsedovanja

Republike Slovenije Svetu Evropske unije

Organizacijsko najbolj zahtevno je srečanje COSAC, saj poleg velikega števila udeležencev predstavlja velik izziv tako organizacijsko kot finančno prevajanje $\vee 23$ jezikov EU. Pri organizaciji tega dogodka je Državni zbor kot nosilec v skladu z dogovorom sodeloval z Državnim svetom.

\subsection{Priprava služb Državnega zbora na predsedovanje}

Z ustanovitvijo projektne skupine (Državni zbor, 2006b) je bila aprila 2006 na novo začasno postavljena organizacijska struktura oz. hierarhija znotraj služb Državnega zbora za čas priprav in izvedbe projekta predsedovanja (slika 1), ki je omogočala kakovostno in učinkovito izvedbo nalog v zvezi s predsedovanjem. Projektna skupina je s svojimi nalogami in pooblastili pridobila potrebnp operativno moč za izvedbo pričakovanih aktivnosti, da je lahko učinkovito izvajala vse naloge. Za potrebe predsedovanja so bili v Državnem zboru sprejeti nekateri novi interni akti (npr.: poseben pravilnik, ki je določal kriterije za finančne dodatke uslužbencem, udeleženim v projektu predsedovanja; vzpostavljena je bila časovnica z roki za izvedbo posameznih aktivnosti,...).

\section{Slika 1: Organizacijska shema vodenja in koordinacije projekta predsedovanja v Državnem zboru}

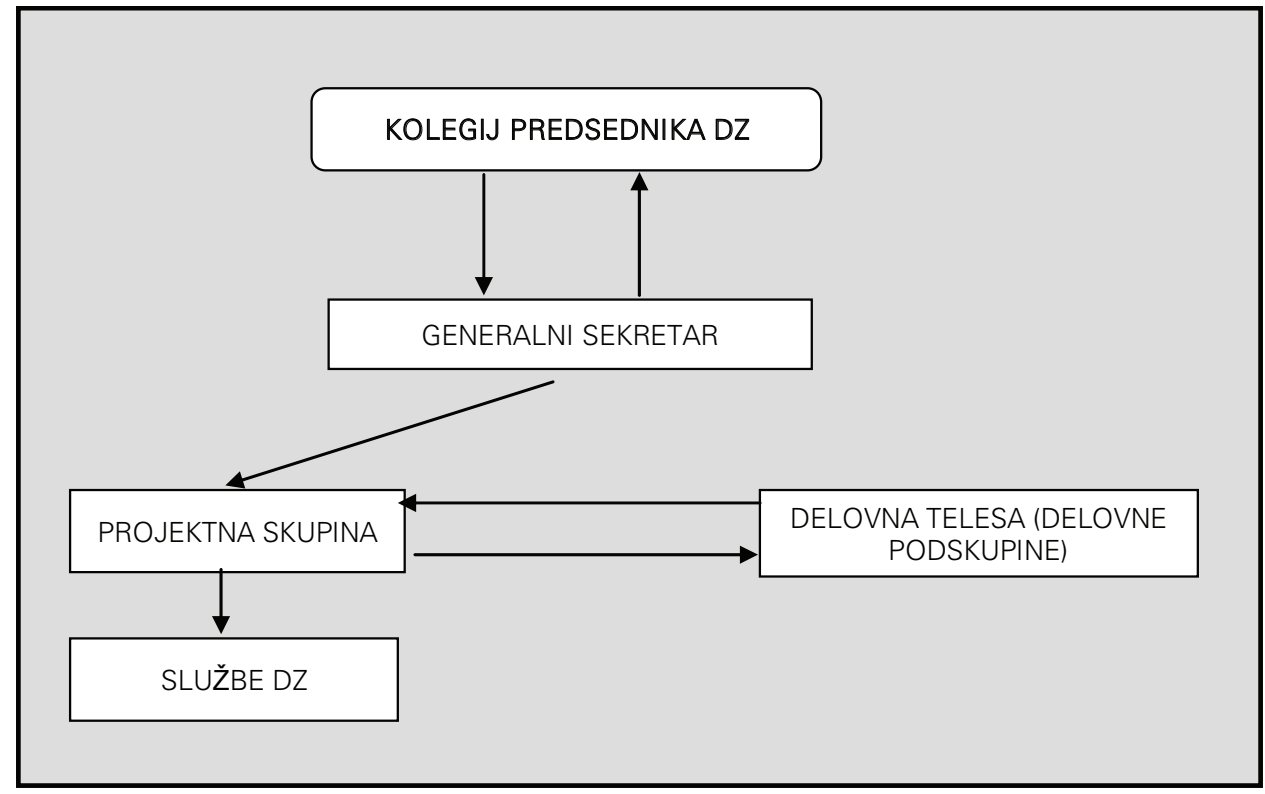

Vir: avtor 
V proračunu za leto 2007 in za leto 2008 je imel Državni zbor predvidena sredstva za deset novih zaposlitev za potrebe predsedovanja. $V$ skladu $\mathrm{s}$ poslovnikom COSAC-a je moral zagotoviti tudi svojega predstavnika $v$ sekretariatu COSAC-a, ki ima sedež v Evropskem parlamentu v Bruslju, za obdobje 18 mesecev (od 1. 7. 2007 do 31. 12. 2008). Dejansko pa je Državni zbor do začetka predsedovanja in $v$ času predsedovanja za potrebe projekta predsedovanja zaposlil štiri nove sodelavce za določen čas do konca predsedovanja (Državni zbor, 2008).

Za izvajanje vseh potrebnih aktivnosti, povezanih s predsedovanjem, je bilo treba zagotoviti ustrezno kadrovsko zasedbo tudi $v$ delovnih telesih (delovnih podskupinah), v katerih je sodelovalo 21 uslužbencev, ki so pripravljali in opravljali vsebinske naloge posameznih srečanj odborov. Pomanjkanje lastnih kadrov se je pokazalo predvsem na področju prevajanja, protokola in na področju odnosov z javnostmi. Druge kadrovske potrebe so se začasno reševale z zaposlenimi znotraj služb Državnega zbora.

Za potrebe priprav in izvedbe predsedovanja je bilo organiziranih nekaj seminarjev in usposabljanj za uslužbence, sodelujoče $v$ projektu, predvsem na področju jezikovnega usposabljanja za različne ravni uslužbencev. Uslužbenci avstrijskega parlamenta so na enodnevnem seminarju v Državnem zboru predstavili svoje izkušnje pri predsedovanju. Predstavniki Vlade so na posebnem predavanju predstavili različne tehnične vidike predsedovanja posamezne države. Konec oktobra 2007 je skupina uslužbencev Državnega zbora, sodelujočih na projektu predsedovanja, obiskala Evropski parlament, kjer se je seznanila s ključnimi značilnostmi priprav skupnih dogodkov oz. srečanj Evropskega parlamenta in predsedujoče države. $V$ okviru priprav na predsedovanje sta dve uslužbenki Državnega zbora dva tedna stažirali na Dunaju v avstrijskem parlamentu.

Služba za odnose z javnostmi v Državnem zboru je skrbela za ustrezno in sistematično informiranje medijev ter za pripravo sporočil za javnost in po potrebi organizirala izjave za medije, poskrbela pa je tudi za postavitev spletne strani predsedovanja s povezavami na druge ustrezne spletne naslove, predvsem pa za ažurne podatke in informacije o aktualnih dogodkih pri pripravi in izvedbi predsedovanja. Vlada je izbrala celostno podobo predsedovanja, ki se je deloma uporabljala pri predsedovanju za potrebe Državnega zbora.

Najbolj pomemben medij za komuniciranje z javnostmi je bilo $v$ času predsedovanja novo spletno mesto Državnega zbora. Novo spletno mesto je bilo za javnost objavljeno v začetku meseca decembra 2007 (Državni zbor, 2009). 
Lovro Lončar

Državni zbor v času priprav in izvedbe predsedovanja

Republike Slovenije Svetu Evropske unije

Spletno mesto je bilo zasnovano po časovnem zaporedju posameznega dogodka v Državnem zboru ali drugod (npr. v Evropskem parlamentu v Bruslju). Pripravljeno je bilo v slovenskem, angleškem in francoskem jeziku.

Na spletni strani predsedovanja je bilo objavljenih 1.253 .020 znakov besedila, 91 priponk $\vee$ Wordovi ali PDF obliki in 624 fotografij. Obiskovalci so $v$ sedmih mesecih opravili več kot 281.000 ogledov strani spletnega mesta predsedovanja. Odziv različnih skupin javnosti (mediji, splošna javnost, strokovna javnost, notranja javnost) ni odstopal od primerljive parlamentarne prakse $\vee$ tujini.

\section{Zaključek}

Predsedovanje Slovenije Svetu EU je bilo nedvomno veliko priznanje, pa tudi dragocena izkušnja za nadaljnje delo v okviru institucij EU. Članek prikazuje le del aktivnosti Državnega zbora $\vee$ času priprav in izvedbe predsedovanja na parlamentarnem nivoju. Poleg navedenih aktivnosti in dogodkov je bila $v$ času predsedovanja izjemno povečana mednarodna aktivnost Državnega zbora, kar se kaže $\vee$ številu neformalnih in formalnih mednarodnih dogodkov $\vee$ Državnem zboru v prvi polovici leta 2008.

Izkušnje pri pripravi in izvedbi predsedovanja na parlamentarni ravni so odraz dobrega in učinkovitega projektnega dela, predvsem pravočasne in kakovostne priprave srečanj, pridobitve koristnih informacij in izkušenj drugih držav predsedujočih, doslednega projektnega dela s poudarkom na koordinaciji, jasnih nalogah in ciljih ter stalne pripravljenosti na takojšen odziv na morebitne nepredvidene dogodke pri izvedbi projekta.

Za vsebino dogodkov je povečini odgovorna politika, za tehnično podporo so odgovorne strokovne oz. tehnične službe. Kakovost dogodka pa se meri po vsebini, ki lahko doseže svoj namen, če je dogodek dobro tehnično in organizacijsko podprt. Službe Državnega zbora so na pripravah in pri izvedbi dogodkov za čas predsedovanja svoje delo odlično opravile in dokazale, da so kos tudi največjim izzivom in nalogam. 


\section{Lovro Lončar \\ Državni zbor v času priprav in izvedbe predsedovanja Republike Slovenije Svetu Evropske unije}

Mag. Lovro Lončar se je po službi svetovalca zaposlitve na Zavodu Republike Slovenije za zaposlovanje leta 1995 zaposlil na občini Domžale kot sekretar občinskega sveta. Leto in pol je bil tajnik Visoke upravne šole v Ljubljani, zatem pa je bil v letu 2000 imenovan za generalnega sekretarja na Ministrstvu za delo, družino in socialne zadeve. Leta 2001 je bil imenovan za sekretarja poslanske skupine v Državnem zboru Republike Slovenije, konec leta 2004 pa za generalnega sekretarja Državnega zbora Republike Slovenije. To funkcijo je opravljal do konca mandata leta 2008. Sedaj je kot sekretar zaposlen na Ministrstvu za delo, družino in socialne zadeve.

\section{Literatura}

- Državni zbor RS. (2006). Predlog priprav na predsedovanje Republike Slovenije Svetu EU od 1. 1. 2008 do 30. 6. 2008 - parlamentarni vidik. Ljubljana.

- $\quad$ Državni zbor RS. (2006a). Aktivnosti Državnega zbora v obdobju predsedovanja EU od 1. 1. 2008 do 30. 6. 2008 (gradivo za 70. sejo Kolegija predsednika Državnega zbora 14. julija 2006). Ljubljana.

- Državni zbor RS. (2006b). Sklep o imenovanju projektne skupine v Državnem zboru za pripravo na predsedovanje Republike Slovenije Evropski uniji od 1. 1. 2008 do 30. 6. 2008. Ljubljana.

- Državni zbor RS. (2007). Gradivo za delovni pogovor vodij poslanskih skupin ter predsednikov delovnih teles o aktivnostih Državnega zbora v času predsedovanja za dne 11. januar 2007. Ljubljana.

- Državni zbor RS. (2007). Informacija o podlagah za skupna medparlamentarna srečanja v Bruslju. Ljubljana.

- Državni zbor RS. (2007a). Časovni in vsebinski razpored sestankov odborov nacionalnih parlamentov, ki bodo potekali v Državnem zboru v času predsedovanja Republike Slovenije Svetu EU. Ljubljana.

- Državni zbor RS. (2007b). Informacija o dejavnostih Državnega zbora Republike Slovenije v času predsedovanja Republike Slovenije Svetu Evropske unije (januar-junij 2008); EPA 1784-IV. Ljubljana.

- Državni zbor RS. (2007c). Dogovor o sodelovanju Državnega zbora in Državnega sveta pri usmerjanju aktivnosti v času priprav na predsedovanje in v času predsedovanja Republike Slovenije Svetu Evropske unije. Ljubljana.

- Državni zbor RS. (2008). Poročilo o pripravah in izvedbi dogodkov v Državnem zboru v okviru predsedovanja Republike Slovenije Svetu Evropske unije. Ljubljana.

- Državni zbor RS. (2009). http://www.dz-rs.si/index.php?id=465. 15. 7. 2009. Ljubljana. 
Lovro Lončar

Državni zbor v času priprav in izvedbe predsedovanja

Republike Slovenije Svetu Evropske unije

- Lončar, L. (2007): Državni zbor Republike Slovenije - vloga in aktivnosti za čas predsedovanja EU. Zbornik 27. Mednarodne konference o razvoju organizacijskih znanosti, Portorož . Kranj: Moderna organizacija.

- $\quad$ Protokol o vlogi nacionalnih parlamentov v EU. (1997). Amsterdam.

- Smernice o medparlamentarnem sodelovanju. (2007). Konferenca predsednikov parlamentov držav članic EU v Haagu dne 3. 7. 2007 ( http://www.ipex.eu). Haag.

- Vlada RS. (2004). Informacija o vrstnem redu predsedovanja Svetu Evropske unije in Evropskemu svetu po letu 2006. Ljubljana.

- Zakon o sodelovanju med državnim zborom in vlado v zadevah Evropske unije (Uradni list RS, štev. 34/2004). 
SUMMARY

\section{THE NATIONAL ASSEMBLY DURING PREPARATI- ON AND IMPLEMENTATION OF THE SLOVENIAN EU COUNCIL PRESIDENCY}

In November 2004 Slovenia was offered, as the first among the new EU Member States after the enlargement in 2004, to assume the Presidency of the EU Council in the first half of 2008 in accordance with the EU Presidency Plan proposed by individual EU Member States. With the decision to accept the presidency and later on with the approval of our presidency in Brussels, the substantive and technical preparation activity for the presidency was initiated.

During the EU Council Presidency (hereinafter referred to as "the Presidency"), the national parliaments organise interparliamentary meetings at three levels: the Conference of Community and European Affair Committees of Parliaments of the European Union (COSAC), interparliamentary meetings of other committees of the national parliaments, organised by the Presidency (in addition to the meeting of foreign affairs committees, a constant feature of each presidency, the national parliament of the presiding country also organises meetings of some other committees - normally three to four meetings in accordance with the past practice ; interparliamentary meetings in cooperation with the European Parliament - co-presidency of joint interparliamentry meetings in Brussels. The Council of the President of the National Assembly at its $95^{\text {th }}$ session on 20 April 2007 approved the timetable and content plan of the national parliaments' committee meetings held at the National Assembly during the Presidency, and at the same time took note of the information on the envisaged interparliamentary meetings in cooperation with the European Parliament and other possible meetings at the National Assembly during the Presidency (e.g. the meeting of the Assembly of the Western European Union and the meeting of the Transatlantic Legislators' Dialogue). Furthermore, the National Assembly at its $34^{\text {th }}$ regular session on 18 December 2007 took note of the Information on the Activities of the National Assembly of the Republic of Slovenia during the Slovenian Presidency of the EU Council (January - June 2008) - EPA 1784-IV.

Key decisions regarding the activities of the National Assembly during the period of preparation and the Presidency (determination of activities, etc.) were taken by the Council of the President of the National Assembly. 
Lovro Lončar

Državni zbor v času priprav in izvedbe predsedovanja

Republike Slovenije Svetu Evropske unije

All activities were managed or coordinated by the President of the National Assembly in cooperation with the Secretary General of the National Assembly and the National Assembly's project group in charge of the preparation for the Presidency (hereinafter referred as "project group"). In this context, preliminary coordination of the National Assembly's regular activities plan, the presidency programme at the parliamentary level, and the programme of other international activities held at the National Assembly during the Presidency, was of utmost importance. In cooperation with the project group, the Secretary General of the National Assembly kept the Council of the President of the National Assembly up-to-date on the course of preparations for the Presidency held at the National Assembly.

The decision regarding which meetings during the Presidency would be organised by the National Assembly, was based on the priorities of the Slovenian EU Presidency and on past practice as regards parliamentary presidency, as well as on substantive priorities of individual working bodies (committees) of the National Assembly. Each presiding country is independent when determining committees or contents for individual meetings.

Individual working bodies (committee presidents or the National Assembly's expert services) were responsible for content-related preparation of parliamentary meetings which involved the responsibility of drafting the substantive part of the programme (determining topics, speakers, coordinating the programme, monitoring the progress of the meeting, drafting of possible conclusions, etc.). According to the latest available information, Slovenia was also the only presiding country to discuss the topics (content) of individual parliamentary meetings in the form of information in the parliament's plenary session (at the session of the National Assembly). In this respect, also the general public took note of the substantive emphases of the EU Presidency.

For the implementation of activities during the Presidency, the Secretary General issued a Decision in April 2006 with which he established and appointed a five-member project group in charge of the preparations for the Presidency, opened to take on new staff if needed. The task of the project group, being the driving force of organisational preparations for the Presidency, was to organise and carry out all activities held at the National Assembly during the Presidency, as well as to ensure coordination with the Government. What needs to be highlighted here was the 
excellent cooperation and coordination with Government services which helped prevent possible duplication of activities and above all reduce unnecessary additional costs (e.g. gifts, transport, security, etc.). In the course of preparation they visited the Austrian and the Portuguese parliament where they shared their experience regarding the presidency. The acquired information was indeed valuable, since there are no written rules or experience in relation to parliamentary activities before and during the presidency

Immediately after the appointment of the project group in charge of the preparation for the Presidency and after the formation of working subgroups for content-related preparation of individual events, a joint meeting of all heads of services and employees of the National Assembly involved in the presidency project and the presidents of working bodies (committees) took place, at which the concept and the organisational structure of the preparation and implementation of individual events were presented, tasks and obligations were assigned, thus preventing possible duplication of activities or competences. In doing so, a temporary organisational structure or hierarchy was established within the services of the National assembly, being in effect during the organisation and implementation of the presidency project. With its tasks and powers, the project group acquired the necessary operative skills with which it was able to efficiently perform all duties. For presidency purposes, a certain number of new internal acts were adopted (e.g. special rules determining criteria for financial allowances of employees involved in the presidency project; a timetable with deadlines for the implementation of individual activities was established).

Each meeting demanded special preparation and adjustment to specific requirements of the event. The most challenging, as regards the organisation of meetings, was the COSAC meeting which, in addition to the large number of participants, also requires interpretation services for 23 EU languages, thus being a great challenge in both organisational and financial terms. In organising this event, the National Assembly as the holder of the event actively cooperated with the National Council in accordance with their agreement.

For the presidency purposes, before the start of the Presidency and during the Presidency, the National Assembly employed four new employees for a fixed term (until the conclusion of the Presidency). For the implementation of all necessary activities related to the Presidency, 
Lovro Lončar

Državni zbor v času priprav in izvedbe predsedovanja

Republike Slovenije Svetu Evropske unije

suitable staff needed to be ensured also within working bodies (working subgroups) in which 21 employees participated and who were in charge of preparing and performing substantive tasks of individual committee meetings. Staff shortage was primarily noted in the area of translation, protocol and public relations. Other staff requirements were temporarily solved by restructuring of those already employed within the services of the National Assembly.

For the purposes of the preparation and implementation of the Presidency, a number of seminars and trainings for employees participating in the project were organised, mostly language training covering different levels of employees' language proficiency. Employees of the Austrian Parliament presented the experience of their presidency at a one-day seminar at the National Assembly. A special presentation was also given by Government representatives who spoke about different technical aspects regarding the presidency of an individual country. At the end of October 2007, a group of the National Assembly's employees, participating in the presidency project, visited the European Parliament where they took note of key features as regards the organisation of joint events or meetings of the European parliament and the country holding the presidency. Within the framework of presidency preparations, two employees of the National Assembly were given a two-week traineeship at the Austrian Parliament in Vienna.

The National Assembly's Public Relations Office was responsible for providing information to the media in a suitable and systematic manner, for drafting press releases, as well as organising statements to the media if necessary. During the Presidency, the most important medium for public communication was the new website of the National Assembly. The new website was launched at the beginning of December 2007. The website was designed according to the chronological order of individual events held at the National Assembly or elsewhere (e.g. at the European Parliament in Brussels). All information included in the website was available in Slovenian, English and French language.

Slovenian Presidency of the EU Council was by all means a great recognition, and also a valuable experience for future work within the framework of EU institutions. The present article only demonstrates a part of the activities undertaken by the National Assembly in the course of preparation and implementation of the Presidency at the parliamentary level. In addition to the said activities and events, the National Assembly 
witnessed a substantial increase in international activity which was reflected in the number of informal and formal international events held at the National Assembly in the first half of 2008.

Experience in preparation and implementation of the Presidency at the parliamentary level is the result of professional and efficient project work, in particular the organisation of meetings in a timely and quality manner, the acquisition of useful information and experience of other presiding countries, the consistent project work with the emphasis on coordination, clear tasks and objectives, and constant readiness to respond to possible unforeseen events in the course of project realisation.

Politics is responsible for the content of events, whereas technical support is provided by expert or technical services. The quality of event is determined according to its content which can only achieve its purpose if the event is given appropriate technical and organisational support. As regards preparation an implementation of events during the Presidency, the services of the National Assembly did excellent work and proved to be able to rise also to the greatest challenges and tasks. 